\title{
Resilience and Early School Age Children's Needs Satisfied Through Art
}

\begin{abstract}
The article is an attempt at describing the relation between resilience and needs. It is based on the assumption that these are two sets of variables vital for harmonious development that resonate with each other in a peculiar manner. Resilience and human needs are both contextually and hereditarily conditioned, but the relation between them seems not necessarily a linear one. In adults, resilience might be a significant medium in the satisfaction of needs and even condition them. In children, however, the relation between these variables is different. A child is born with certain potential determining its level of resilience, but deprivation of their key needs, especially during first years, might simply impair their development or disturb its synchronisation. The main issue discussed in this article is the basis of the relation between resilience and the needs that must be satisfied at school. The article contains observations made while carrying out an experimental project that enables the youngest pupils to access and fulfil their multidimensional needs.
\end{abstract}

\section{Keywords:}

resilience, needs, early school age children, art, experiment

\section{INTRODUCTION}

Scientific analyses concerning the issue of resilience gain importance as one realises how much our era is permeated with accidentality. For this reason, resources enabling resilience are becoming a condition necessary to live in such an era. They

1 Department of Pedagogy and Psychology, University of Silesia in Katowice, Poland, E-MAIL: laczykm@interia.pl. 
enable us to live a life that is more than merely the everyday, they make us prepared a life "on the edge", a life marked by the necessity of oscillating between what we know and what is tamed, and that which is even difficult to predict. It is necessary to discuss these issues when we consider the struggle to "tame" reality, which today is the struggle of every human being, regardless of their age. If one accepts such a perspective, one might find resilience a key form of capital, necessary in a world of permanent change and contemporary forms of risk and dangers. Bauman (2011, p. 183) calls these dangers "unnamed, unpredictable and undefinable". We ought to perceive resilience as an important factor in positive adaptation to reality, which can be observed in moderating one's life always in an active and creative way, setting up goals and facing challenges.

\section{CONDITIONS FOR RESILIENCE - A SYNTHESIS}

From a scientific point of view, resilience is a sum of an individual's biological potential, including intelligence and temperament, and environmental variables, such as the atmosphere in family or extrafamilial system of support (Opora, 2008). The process of resilience development remains under a significant influence of endogenous factors, i.e., cognitive abilities and temperament. The latter is responsible, among others, for how energy is accumulated and released and the choice of activity, dependent on the individual's need for stimulation (Eliasz, 1981). On the other hand, biological potential interferes with exogenous, environmental factors. Altogether they create a space for development that is always unique and responsible for its varied outcomes. The specific constellation of forces and dynamics present in upbringing and development might function in two ways. It might, since one's early years, help to keep balance and create foundations for shaping a transgressive attitude to life. It might also be considered a risk factor in the appearance of incapacitation and helplessness, which do not accompany resilience. Opora (2008) mentions early signs of resilience typical for children, pointing to the role of genetic and neurochemical factors identified in various studies. Having read Opora's article, one observes that, even at early stages of development, resilience correlates with sociability, intelligence, determination, sense of control, and androgyny. Moreover, it is more typical for children who have a higher chance of developing resilience to cooperate, postpone gratification, strive for mastery, and have high self-esteem (Opora, 2008). A child possessing these qualities is more likely to be more effective in dealing with difficult situations. These features also prevent, to some extent, the risk of "the nightmares that pester the inhabitants of 
our world [...]" being "exclusion, [...] ostracism, refusal of entry, neglect, being pushed aside...” Both quotes from Bauman (2011, p. 191) are becoming reality. Unfortunately, these phenomena seem most material these days. While Bauman's position ought to be interpreted rather as relating to the generation of adults, it is worth remembering about when one considers the assumptions made in a project of early stage education. In this context, developing resilience calls for special consideration, as it is tightly bound to an individual's participation and self-actualization at every stage of life.

\section{PUPILS' NEEDS AND RESILIENCE IN THE LIGHT OF ADAPTATION TO SCHOOL}

Much of our most important emotional and interpersonal learning occurs during our first few years of life, when our more primitive neural networks are in control. Early experiences shape structures in ways that have a lifelong impact on three of our most vital areas of learning: attachment, emotional regulation, and self-esteem. These three spheres of learning establish our abilities to connect with others, cope with stress, and feel that we have value. Every time children behave in a way they (or we) do not understand, a teacher has the opportunity to engage in an exploration of their inner world. When painful experiences can be consciously thought about, named, and placed into a coherent narrative, children gain the ability to reintegrate dissociated neural networks of affect, cognition, and bodily awareness (Siegel, 2012).

From a pedagogical perspective, it is important to shape and help develop, even in youngest children those features that will enable them to overcome difficulties, avoid frustration caused by failure, manage tasks and stress in an optimal manner, and achieve their personal goals. Thus, the most important are obviously the first years of development, when a particular "matrix" of personality is formed. It consists of, among others, cognitive representations and expectations. It is also during the first years that experiences constitute a basis for solidifying personal narratives, which, in addition to other functions, "control the processes of understanding and decision-making” (Trzebiński, 2002, p. 23). Needs are an important factor in personal development, for they are both a source of activity and an indicator of how far an individual is from their living optimum (Lisowska, 2008, pp. 86-87). The extent to which needs are satisfied decides about an individual's mood, strivings, behaviour, and goal-orientation. The stronger the tension related to a need, the greater the determination to satisfy it. In adults, resilience 
decides, e.g., on the ability to resist even the level of frustration present in situations of long-term needs deprivation. However, how resilient one is going to be in such situations will depend on both the biological potential and the possibility to satisfy all the needs in the biological, social, cultural and personality spheres, present since the first days of one's life. Proper efforts aimed at the satisfaction of needs lay early foundations for development of potential, broadly understood, including social and emotional competence and future-oriented attitude, all three of which Grzegorzewska (2011) perceives as indicators of resilience. She stresses the importance, among the components of emotional competence, of positive selfesteem and an inner sense of control. These features develop well primarily in an atmosphere of love, acceptance, safety, and autonomy, balanced with proper setting of boundaries.

An optimal atmosphere of upbringing and development, as well as a suitable quality of relationships or bonds (Bowlby, 2007), form a basis for developing optimism, faith in oneself, stability, cognitive openness, and a tendency to explore. This correlates with a courage to face challenges and the development of the feeling of agency and motives for control. Experiencing oneself as a subject-agent is also correlated with the development of a feeling of control, self-evaluation, which altogether decide about the attitude to potential failures, about the approach to difficult situations and challenges. Since needs are identical with tension, drive for action, they will be a primary motive for certain actions and behaviours that, in adverse conditions, might as well exclude an orientation towards actions strengthening resilience. Such a thesis is justified especially in the light of the definition of needs making us consider them "a physico-chemical force at work in the brain, organising thinking, perception, apperception, and the drive for action aimed at altering an unsatisfactory situation and eliminating the tension which such a situation is generating” (Siek, 1983, pp. 189-190).

As it has already been stated, both resilience and the state of satisfaction of a child's needs depend on environmental variables. It is obviously how the family functions that has the greatest influence on the course of the process of development. However, immediately after the family, the duty to care about a child's well-being is, to an extent parallelly, delegated to the kindergarten and later to the school. It is when a child goes to school and enters the role of a pupil that their resilience is verified. A competent teacher will easily assess it. Such assessment is possible thanks to the fact that children's attitudes, strivings and reactions are naturally more vivid, easily perceivable, indicating the direction of a child's development - either harmonious or abnormal. In order to support resilience, it is crucial to be able to diagnose deficits in the area of children's needs. It is so, 
because the frustration resulting from a significant "feeling of lack" will lead to fixating on selected, narrowed-down goals. Thus it will weaken their drives and motivation for the things that facilitate multidimensional development and strengthen personality, or indeed resilience itself. Hence, it ought to be possible, since the beginning, for the youngest pupils to satisfy their various needs within the environment of their school. However, it is also important to direct these needs well, as well as kindle or keep up the needs that are particularly important for the formation of personality. These are the needs responsible for a tendency to explore one's own significance, to gain a feeling that control is attainable, the needs that facilitate developing autonomy and building a sense of one's own value. Creating circumstances suitable for satisfying all these needs is a decisive factor in strengthening a child's subjectivity and self-acceptance, eliminating fear of failure and, instead of this fear, developing faith in one's ability and stimulating a need to cross one's own barriers and boundaries. To release in children-pupils such tendencies is necessary for strengthening, or even shaping anew, the basis for their resilience.

Along the path of development, children's needs undergo individualisation, but up to certain period they do show some similarity. In line with the hierarchy set up by Maslow (1990, pp. 82-86), physiological needs, the need for safety, belonging, love, esteem, and self-actualization can be considered universal. They are linked to the need for autonomy, independence, exploration of the world and action aimed at self-cognition, self-understanding and self-definition. Entering the role of a pupil is formally linked to discovering "a different version of oneself", enriching the narratives concerning the environment and one's participation in or meaning for it. This meaning however, in the phase of latency, as described by Erikson (2004) in his psychosocial theory of development, is not formed "here and now". It depends on how previous crises were solved. Nonetheless, at this particular stage of development, the feeling of personal meaning is particularly likely to be fed with proper attention and recognition from significant others, including teachers, parents, and peers. Bearing in mind the essence of the relational character between needs and resilience, we ought to stress one fact. It is that during the crisis between productivity and inferiority (the phase of latency), a child wants particularly, more and more consciously, to exist as a unique agent. Satisfying these tendencies is an important factor in the process of strengthening the child's whole-life situation and enriching their capital, which is the locus of their resilience. Therefore, the age of competence is specifically revolutionary. The child is strongly driven by the aforementioned "need for esteem, achieving positive results, a striving for perfection” (Appelt, 2005, p. 296), as well as by related cog- 
nitive, exploratory needs. Those latter needs, properly kindled by teachers, usually translate into the pupil's intellectual activity, sought after by the school. It is now worth recalling how Kielar-Turska specifies them as needs for:

- "exploring, getting closer to objects, manipulating them, asking questions and making hypotheses;

- labelling, i.e., striving to separate the objects one learns about, marking them as known by means of naming them;

- freshness, which shows in an active search for "novelty" of an object by means of trying to apply to it the ways of acting the child already knows;

- things known, which shows in a tendency for repetition aiming at reinforcing an expected result or bringing it about yet another time;

- asking questions;

- describing the world, striving to present one's knowledge on every subject interesting for the listener” (Kielar-Turska, 1992, pp. 171-182).

Stimulating cognitive needs is a basic goal embedded in educational activity. These needs, however, ought to have a status equal to other needs, assuring a state of biopsychophysical balance in the youngest. It is undesirable when, at the very onset of education, pupils experience their "agency" and pride of achievements related only to attention and reward for intellectual achievements, restraint, and a tendency to be adequate, which is also natural and, according to Kohlberg, typical at this stage of development. By being adequate I mean not an ability to adapt, being a sign of discipline and internalisation of rules regulating functioning in society - such an ability is a desirable effect of educational activity. I deem being adequate related to conformism and incapacitation. Unfortunately, this tendency in a child can be used in a particularly oppressive way. It occurs when bans become a dominant factor in working with a pupil and obedience, natural at this age, is used, in a situation of power, to exercise "authority" over them. Creating an oppressive atmosphere is a total threat for development and immediately blocks pleasant emotions and excitation, which constitute a motivating factor for learning. What is more, they are a factor in facilitating the development of resilience.

Yet another factor of either risk or opportunity in the process of developing a pupil's resilience is their attitude towards school. In the first years of education, school is normally a source of pleasant experiences. Nevertheless, much depends on how quickly children internalise the norms they are subjected to and on the extent to which teachers manage to balance their contradictory strivings, present, e.g., in simultaneous needs for freedom and subordination. Pushing the rule of spontaneity to the background and disrespecting the playful atmosphere which enables complete expression are attitudes that block children's potential. 
In such an atmosphere, all they do is mechanically adopt rules and they have no chance for trying themselves in untypical, new, unexpected situations that would require them to implement novel solutions or prove their effectiveness. Activisation and learning by doing is the best foundation for the development of any type of competence, including cognitive, emotional and social competence, which are components of resilience. A factor deserving a special mention is also the need for creating.

Nowadays, the significance of creative, also self-creative, activity is being constantly highlighted. Unfortunately, an analysis of current scientific data proves that we constantly need to highlight the issue of this type of activity being marginalised. For it proves that, in practice, creative needs or competences are still being appreciated rather "by the way" or when they are missing. Meanwhile, these days, the acquisition of such competences is considered a sine qua non of success. Moreover, it is a constituent of education for harmonious development, a development based on stimulating in children courage, well-understood expansion, their openness to new challenges. All situations making a pupil act as an active subject, inspiring them to be independent, to create, to solve problems in a suitable atmosphere that does not penalise mistake or error, they create the right context for supporting the need for being effective and for autonomy, both needs being important at this stage of life. This undoubtedly creates a basis for the formation of self-esteem, which is also mentioned as a determinant of resilience. If we consider those issues important, it is necessary to consider the status of purely intellectual and creative activity at school. In order to do this, it is worth observing whether a proper proportion holds between adaptation-oriented actions and evoking ones. The latter are such actions that make a child act not only reactively, but also in a way that allows them to satisfy their individual needs by discovering who they are, who they can be, and that they are unique. This cannot be achieved without circumstances facilitating complete expression. Ensuring such a standard minimises the risk of standardisation and "formatting” needs as well as pupils themselves.

School is not a place where individualised strivings are always accepted. The response to children's needs, either in the form of acceptance or the lack of it, makes them intensify reflection and observation and change their strategies. Obviously, much depends on a child's alertness, their sensitivity, advancement in their emotional development, and the way they perceive their position within a group's structure. It is also natural for needs to undergo ceaseless transformations. This results to an extent from the pace and dynamics of development, which is determined by biological forces harnessed by qualitatively different spaces of upbring- 
ing and socialisation. Even though the outcome of such a relation is always varied, there is no doubt that every child, every pupil beginning their education usually needs attention, recognition and approval, which might be deemed priorities in the process of strengthening a child's resilience. The awareness of the significance of individual needs is linked to a necessity of granting them a space for realisation. Unfortunately, the classroom is not always an environment that would allow pupils to experience affirmation resulting from experiencing oneself as a competent and agentive subject. The interaction between the teacher, the pupil and the learning task is a fluid dynamic whereby the task is a reflection of the teacher's awareness and understanding of the pupil and the pupil is able to seek reliable support when challenged by the task. Each relates to the other in a way that fosters curiosity and supports the uncertainty that can be created by the challenges of not knowing, which is at the heart of all learning (Geddes, 2006).

\section{ART FOR SATISFACTION OF NEEDS AND SUPPORTING RESILIENCE OF EARLY SCHOOL-AGED CHILDREN}

Creating opportunities for complete expression, experiencing one's subjectivity, is not always possible in standard school conditions. For these conditions are still based on a "model of the student's passive brain” (Adamek \& Bałachowicz, 2016, p. 10) and deviations from this rule are still merely incidental. While a departure from the standard of a transmissive school is possible and necessary, it requires a global change in thinking about the function and quality of education. It is for this reason that I find it worthy to refer to an alternative, non-traditional form of art-based class. ${ }^{2}$ Such a form makes it easier, in a well-organised process, to discover and reach children's opinions and release that which in directed tutoring remains within the unconscious domain. It would be out of scope of this study to provide a comprehensive review of the functions art can have in human development. Nevertheless, it is necessary at this point to set up at least a narrow theoretical framework for the practical actions to be presented. Thus, a position important for the present deliberations is the contemporary, well-based and well-documented, position of neuroaesthetics. This discipline provides grounds for a claim that works of art can be seen as potential stimuli for the limbic system. Activation of the limbic system makes one feel moved, surprised, happy, nostalgic, or emotional

2 Katarzyna Krasoń is the manager of the exploratory-innovative pedagogical experiment. The goal of the experiment is the actualisation of modal and creative potentialities of pupils from grades 1-3 as key competences through integral cultural expression placed in visual arts. 
in other ways, including the aesthetic. Research in neuroaesthetics, a discipline funded by Zeki (1999), proves the existence of peculiar regularities and making one realise that contact with art (i.e., with an artistic stimulus) is never devoid of meaning. For example, the brain's specific activity might depend on the aesthetics, subjects or category of a perceived work of art (Kawabata \& Zeki, 2004). It might also depend on the perceiver's aesthetic preferences (Vartanian \& Goel, 2004).

Experts in the field say: "The work of visual art is on the one hand a stimulus affecting perception and emotions compliant with standard laws of human psychology and physiology, but on the other hand, it is a unique type of stimulus. Due to artistic deformations, omissions and shifts in composition, it is often a greater challenge for perception and emotions than an ordinary object" (Markiewicz \& Przybysz, 2007, p. 121). Such stimuli are indispensable in stimulating imagination, which seems to be in decline today. Concerns on this issue include this expressed by Francuz (2007), who points out the following: "The civilisation of an image continues to fill areas of human imagination more and more tightly, leaving less and less room for imagination to create, freely and spontaneously, impossible worlds. There is no need for us to imagine virtually anything these days, as we can see virtually everything on billboards, cinema screens or in school books. The process of education concerning the understanding of visual arts and the new media as well as the development of imaginative skills is virtually disappearing” (Francuz, 2007, p. 12)

There are many scientific studies currently available that corroborate the effectiveness of educational or therapeutic activities operating through art. The power of art can be observed for example in Krasoń and Mazepa-Domagała’s study proving that fine arts "release man's spiritual potential, [...] intensify his personal life, [...] prevent him from remaining indifferent to the things they made him experience, things he learned through them or thanks to them” (Kiereś, 1994, p. 53, after: Krasoń \& Mazepa-Domagała, 2004, p. 9). According to Krasoń, the contact with art enables humans to satisfy their fundamental needs for: presence, meaning, participation, and self-revelation. All these needs can be satisfied simultaneously when contacts with art are, to put it synthetically, a prompt for dialogue, reflection, discovery of meanings and their intersemiotic decoding, which opens one to sensual experience, understanding, and unlimited creation (Krasoń \& Mazepa-Domagała, 2004, pp. 11-13). Such a relation with art facilitates inclusion and helps to develop expansion, which allows a child to verify their abilities, overcome limitations, develop competences enabling a better understanding of the environment and self. From the above results a strengthening of control-over-reality motives, which intertwines with greater chances for enhanced resilience. 
Before the methodological aspects of the research are discussed, it ought to be mentioned that the research has multiple aims. However, while bearing in mind the collective character of the research, I shall focus only on the present author's personal aims. As the experiment is a part of a longitudinal study, the major focus has been on grasping the dynamics of changes in the range of needs observed in children, and especially on the hubristic need. The whole procedure started with a pilot study aimed at gathering initial observations, formulating working versions of research questions, and designing an explanation of own research, initially based on a general theoretical framework. Such an explanation appeared with carving out the present author's own module of the research. It was at this stage already that workshops with pupils based on visual arts were organised. The workshops were based on the approach to research by the project manager, Prof. dr hab. Katarzyna Krasoń. The inductive procedure of the first stage of research brought about many questions, including hypotheses, that did not lend themselves to taxonomisation or grading. Generally, the focus was on all possible manifestations of the hubristic need. The manifestations were singled out based, although not exclusively, on an analysis of J. Kozielecki's (1986, 2002) ideas. The primary leading assumption was that the hubristic need manifests itself in crossing borderlines, which Kozielecki deems equivalent to transgression and connected to positive expansion, courage, and creativity. Very briefly to recall those ideas, fundamental symptoms of the hubristic needs were identified as a drive to "marking space with one's presence", cases of self-affirmation, and the child's attempts at discovering new individual possibilities and entering the role of autonomous actor-subject. Further stages of research and experimental procedures, together with scientific literature analysis, allowed to refine the research project, systematise its aims and issues to be investigated, and diversify research techniques. However, it would be difficult to describe all these in detail here. Currently, empirical material is still being collected. It is based on the tool designed by the present author as well as other tools, both standardised and observations or interviews. The object of analysis are those needs of the children that were deemed to be connected with the hubristic needs. At this stage, environmental and personality-related variables will be controlled as well. Resilience is yet another important variable, more typical for individuals effectively satisfying their needs. Resilience correlates with a feeling of competence and acting effectively in situations that are new, non-standard, and thus not always easy to find a solution for.

Education without art has none but the intellectual dimension. One may, somehow metaphorically, consider it deprived of the heart note. Heart and reason, these two spheres ought to intertwine, especially when we consider a harmony of rationalism and the sphere of senses, intuition, imagination, creativity. Art makes 
us more sensitive, opens us to experiences, releases intuitive, imaginative thinking. First of all, however, it is indispensable for the humanistic dimension of our being. The above conviction has been amplified with the observed activity of children participating in the project. Basing on research that is classified as longitudinal, it can be claimed that the classes serve to satisfy multiple needs simultaneously.

These needs are often at the same time new to the children and necessary for their harmonious development. I maintain that such state is absolutely desirable if we care for strengthening a child's resilience. All children's behaviours and their situational needs are easily identifiable during the classes. Individualised observations of children's behaviours are obviously insufficient for establishing individual hierarchies of their needs, as those needs constantly interweave. Nonetheless, at this stage some needs might be considered more typical for particular pupils. Pupils' needs are “cut to fit” by means of Lisowska’s (2008, pp. 101-110) classification of needs, based on Murray's system (1938, after: Lisowska, 2008, pp. 101-110). Indicators of those needs, resulting from certain behaviours exhibited during group classes, allow a diagnosis of tendencies both to get involved and to become more autonomic. These are determined by the needs for: safety, feat, associating, autonomy, compensation, submission, dominating, protecting, play, rejecting, isolating, experiencing care and support, understanding, and creating.

The exhibited works of art serve as a source of inspiration, they release pupils' varied activity. Thanks to the intersemiotic strategy, they lead to the pupils' entering into a peculiar "dialogue" with them. With the goals of the project in mind, the shift of stress towards acting independently and expressing oneself through acts of not only verbal, but also artistic, emotional, and motoric expression seems important as well. The need for movement, being a key one at this stage of development, is being translated into bodily forms of narrating stories, experiences or events. This, in addition to a stimulation of imagination, enriches and supports the process of developing both one's knowledge and the awareness of self and others (intrapersonal and interpersonal competences). Also, children's courage, expansiveness and their motives for transgression are released. The motor for these motives is the hubristic need, heretofore unmentioned. A departure from the transmissive understanding of education leads children to create "impossible worlds". The final effects seem to be surprising for the young creators. However, it happens also that this collage is to a large extent based on behavioural patterns, symbols or events from computer games that have had a lasting effect on the psyche. Unfortunately, in some children these prove to fill their minds rather tightly. Nonetheless, contact with art creates a space for change or enriching associations that are undesirable from the perspective of development. 
Temporally unlimited classes allow children to experience positive emotions. A particularly important one is interest, which constitutes a foundation for creative action, self-expression (either intellectual or motoric), and embracing tasks, all of which sometimes being challenging for the youngest. An example of such a challenge is negotiating meanings resulting from the analysis of presented works. It sometimes happens, however, that negation and rejection of activity appear. Among probable reasons of such reactions we could list pupils' lack of concentration, varied levels of perception and cognitive skills, or simply other occasionally working "variables" such as, e.g., lower mood or hyperactivity. Such behaviours might also result from lack of compatibility of experiences new to them with their everyday experience, rather evidently "rooted" in the virtual worlds of the Internet or television. Today, these media are a natural space of reference. They often mercilessly colonise children's experience since the earliest years. As a result, it is sometimes more difficult to gain the youngest pupils' "approval" for actions forcing them to concentrate on a task for a longer period or fantasise and use their imagination.

\section{CONCLUSIONS}

The effect the works used in the project have on children is a long-lasting one. It is a good omen, especially if we support Szuman's claim that:

A work of art allows one to grasp with one's perception the similarities and differences between people. It allows a realisation of what is moral and commendable and what is not, and why it is so, i.e., what might evoke social acceptance or social negation. Upbringing through art is not only individual-oriented, it is also directed towards the society. The goal is for art to become a common and wanted value, to make human life happier and more valuable (Szuman, 1975, after: Lach-Rosocha, 2013, p. 360).

The project seems a perfect bridge between children's need for being together and a stimulation for undertaking personal goals. The meetings with pupils within the experiment are first and foremost an occasion to experience situations enabling experiencing oneself as an autonomous subject enjoying both individual and communal success. In most cases, the intertwining types of activities make children more dynamic as it enables the satisfaction of social needs, becoming a source of and a basis for making comparisons, registering others' reactions and their social outcome, generating knowledge, and discovering the truth about oneself, which is 
a foundation for personality-related needs. Today, in an era marked by reification of social relations, such an opportunity to initiate these relations, to enter into a conversation leading to an expression of judgements, observations, giving arguments and counter-arguments, seems priceless and much in demand. The classes usually conclude with an exhibition of works, e.g., in the form of drawings containing either symbolic or more realistic "equivalents" of the interpretation of a work of art, which is another stage, in which every child yet again makes their views known, discovers themselves, often freeing themselves from schemas and simple mental relations. Drawing inspiration from the content of the works exposed, the participants undergo a holistic activisation as co-creators and creators. By experiencing themselves in new situations, they have a chance to gain competences decisive for the ability to retain homeostasis and psychological balance, which is in turn decisive in adapting to living in conditions marked by change. The Allen's report (2011) advocates that parents and key professionals need to have the understanding and knowledge of how to build social and emotional capability within children and therefore empower individuals to break inter-generational cycles of dysfunction and underachievement.

\section{References:}

Adamek, I., \& Bałachowicz, J. (2016). Pomiędzy dwiema edukacjami. Łódź: Wydawnictwo Naukowe Wyższej Szkoły Pedagogicznej.

Allen, G. (2011). Early Intervention: The Next Steps. An Independent Report to HM Government. London: The Cabinet Office.

Appelt, K. (2005). Wiek szkolny. Jak rozpoznać potencjał dziecka? In: A.I. Brzezińska (Ed.), Psychologiczne portrety człowieka (pp. 259-301). Gdańsk: Gdańskie Wydawnictwo Psychologiczne.

Bauman, Z. (2011). 44 listy ze świata płynnej nowoczesności. Warszawa: Wydawnictwo Literackie.

Bowlby, J. (2007). Przywiq̨zanie. Warszawa: Wydawnictwo Naukowe PWN.

Eliasz, A. (1981). Temperament a system regulacji stymulacji. Warszawa: PWN.

Erikson, E.H. (2004). Tożsamość a cykl życia. Poznań: Wydawnictwo Zysk i S-ka.

Francuz, P. (Ed.) (2007). Obrazy w umyśle. Studia nad percepcjq i wyobraźniq. Warszawa: Wydawnictwo Naukowe SCHOLAR.

Geddes, H. (2006). Attachment in the Classroom: The Links Between Children's Early Experience, Emotional Well-being and Performance in School. London: Worth Publishing.

Grzegorzewska, I. (2011). Odporność psychiczna dzieci i młodzieży - wyzwanie dla współczesnej edukacji, Teraźniejszość. Człowiek. Edukacja. Kwartalnik Myśli SpołecznoPedagogicznej, 14(1), pp. 37-51. Retrieved from: http://bazhum.muzhp.pl/media//files/ Terazniejszosc_Czlowiek_Edukacja_kwartalnik_mysli_spoleczno_pedagogicznej/ Terazniejszosc_Czlowiek_Edukacja_kwartalnik_mysli_spoleczno_pedagogicznejr2011-t-n1_(53)/Terazniejszosc_Czlowiek_Edukacja_kwartalnik_mysli_spoleczno_ 
pedagogicznej-r2011-t-n1_(53)-s37-51/Terazniejszosc_Czlowiek_Edukacja_kwartalnik_mysli_spoleczno_pedagogicznej-r2011-t-n1_(53)-s37-51.pdf

Kawabata, H., \& Zeki, S. (2004). Neural Correlates of Beauty, Journal of Neurophysiology, 91(4), pp. 1699-1705.

Kielar-Turska, M. (1992). Jak pomagać dziecku w poznawaniu świata. Warszawa: WSiP.

Kozielecki, J. (1986). A Transgressive Model of Man, New Ideas in Psychology, 4(1), pp. 89105.

Kozielecki, J. (2002). Transgresja i kultura. Warszawa: Wydawnictwo Akademickie Żak.

Krasoń, K., \& Mazepa-Domagała, B. (2004). Przestrzenie sztuki dziecka. Strategia intersemiotycznego i polisensorycznego wsparcia jednostek o obniżonej sprawności intelektualnej. Katowice: Oficyna Wydawnicza Librus.

Lach-Rosocha, L. (2013). Pedagogia przeżycia estetycznego w wychowaniu człowieka jako osoby. Kraków: Oficyna Wydawnicza Impuls.

Lisowska, E. (2008). Diagnostyka pedagogiczna $w$ pracy z dzieckiem i rodzinq. Kielce: Wszechnica Świętokrzyska.

Markiewicz, P., \& Przybysz, P. (2007). Neuroestetyczne aspekty komunikacji wizualnej i wyobraźni. In: P. Francuz (Ed.), Obrazy w umyśle. Studia nad percepcja i wyobraźniq (pp. 111-148). Warszawa: Wydawnictwo Naukowe Scholar.

Maslow, A. (1990). Motywacja i osobowość. Warszawa: PAX.

Opora, R. (2008). Praktyczne implikacje wynikające z badań nad odpornością psychiczną u dzieci i młodzieży, Studia Gdańskie. Wizje i Rzeczywistość, 5, pp. 97-108. Retrieved from: http://www.studiagdanskie.gwsh.gda.pl/pdfy/studia5s97-108.pdf

Siegel, D. (2012). The Developing Mind: How Relationships and the Brain Interact to Shape Who We Are. New York: Guilford Press.

Siek, S. (1983). Wybrane metody badania osobowości. Warszawa: Akademia Teologii Katolickiej.

Trzebiński, J. (2002). Narracyjne konstruowanie rzeczywistości. In: J. Trzebiński (Ed.), Narracja jako sposób rozumienia świata (pp. 18-39). Gdańsk: Gdańskie Wydawnictwo Psychologiczne.

Vartanian, O., \& Goel, V. (2004). Neuroanatomical Correlates of Aesthetic Preference for Paintings, NeuroReport, 15(5), pp. 893-897.

Zeki, S. (1999). Inner Vision. An Exploration of Art and the Brain. Oxford: Oxford University Press. 